ISSN No. 0974-035X

An Indexed, Refereed \& Peer Reviewed Journal of Higher Education Towards Excellence UGC-HUMAN RESOURCE DEVELOPMENT CENTRE,

\title{
MARA-VIJAYA OF THE BUDDHA: A CASE STUDY OF BUDDHIST ART FROM PENINSULAR INDIA
}

\section{Dr. Sabita Kumari}

\begin{abstract}
This paper is an attempt to study the verbal discourses in general and visual depictions of Peninsular India in particular related to the theme of Mara-vijaya of the Buddha. It closely studies the panels depicted Mara's attack and the great victory of the Buddha from various sites of Peninsular India.
\end{abstract}

Key words: Buddha, Peninsular India, Aniconic art.

\section{Introduction:}

In the Buddhist tradition, Mara is understood as an evil spirit, who always tries to dissuade people from the path of righteousness. There are various texts such as Mahapadana Sutta, Mahavastu, Lalitha Vistara, Buddha Charita, Nidana Katha and Abhinishkramana Sutra, which narrate the story of Mara, who tried to disturb Siddhartha Gotam, either before or after his attainment of the enlightenment. Nidana Katha and Lalitha Vistara particularly unfold the detailed description of Mara's visit to the Buddha just before his enlightenment. When Siddhartha Gotam was meditating under the Bodhivriksa, Mara along with his ten-fold army appeared to distract him. However, they could do no harm to the Buddha and then Mara's 
daughters came to seduce him. Eventually they had to flee as well. Then the Buddha called the mother earth to be his witness, by touching the earth with his middle finger. The earth gave a response by roaring and bore the testimony for the Buddha. Thus, Mara realized his defeat and went back.

\section{Visual Narration:}

This episode of Mara's assault on the Buddha has been immortalized in the sculptural art of Peninsular India. Peninsular India is southern portion of India, it comprises present days Andhra Pradesh, Telangana, Karnataka, Tamilnadu and Kerala. From the material culture and archaeological remains, we find that Andhra Pradesh is one of the regions having the maximum number of Buddhist site. The evidence suggests that Buddhism flourished in this region before the Mauryan period. However, with the expansion of Mauryan Empire up to Pennar River and the adoption of dhamma by Asoka, Buddhism found numerous patrons. Later, the Satavahanas and the Ikshvakus also patronized the Buddhism. Many Buddhist sites were discovered in the trade routes in the Krishna Godavari river valleys. We find numerous Buddhist establishments all along the Andhra Coast. The efflorescence of Buddhist art from this region, especially the Krishna Valley, is such that a separate prominent school of Buddhist art known as the Amaravati School of Art has originated in this region. 




Mara-vijaya of the Buddha, Ghantasala, Musee Guimet, Source: <http://en.wikipedia.org/wiki/Mara_(demon)>

The panel from Ghantasala represents a conflated narration (Dehejia, 1997:25-27.) of the assault. In this depiction, the Buddha is not shown in physical form. His presence is suggested by indexical signs such as the cushions on the decorated simhasana and a pair of footprints on the pedestal. The mutilated depiction from Ghantasala (Rea, 1894, repr. 1897:37) shows the aggressive attack of Mara and his demon army on the Buddha from left, and the right side is the defeat of Mara, as here they are shown going back in anjalimudra. Right behind the simhasana, there is a Bodhivriksa. The deep undercut carvings of the leaves and the branches projecting more realist image of the tree. Females are also shown standing, possibly the daughters of Mara. 


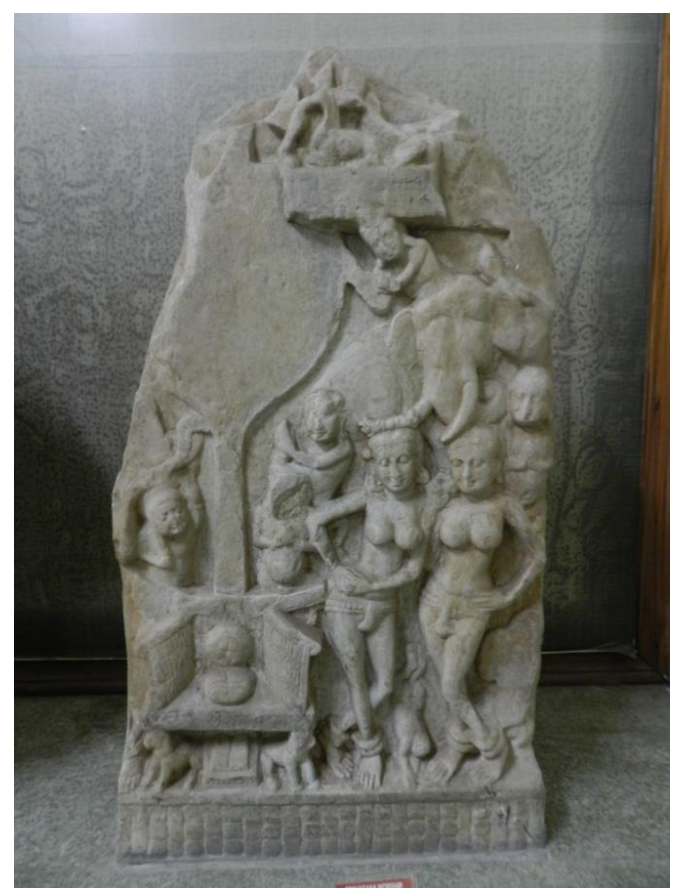

Mara-vijaya of the Buddha, Nandayapalem.

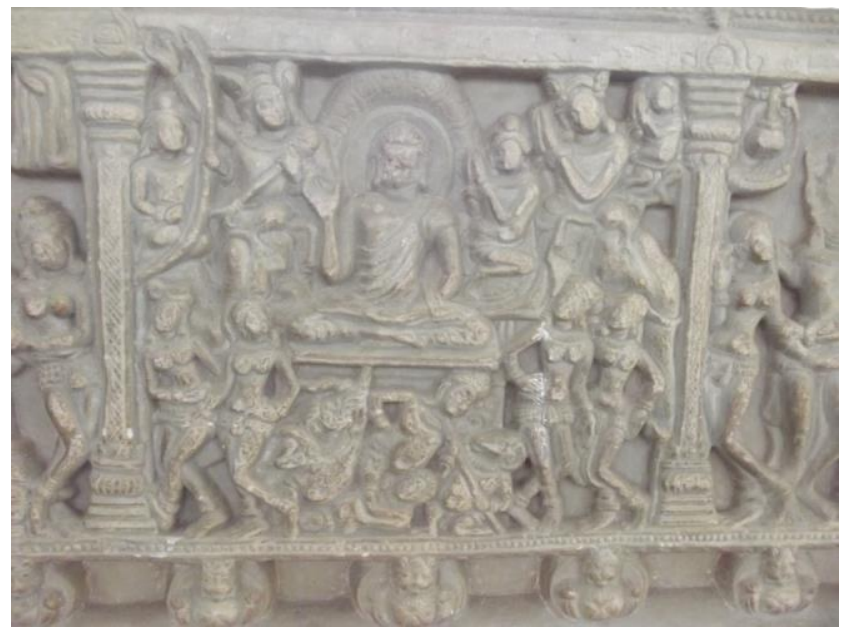

Mara-vijaya of the Buddha, Nagarjunkonda.

In Nandayapalem, we see a low relief carving of the tree and leaves. Here the shape of the empty throne is square, unlike Amaravati where it is round. Usually, the simhasana is shown with curved animal legs. This mutilated panel depicts the defeat of Mara, as he is shown in the anjalimudra mounting the elephant Girimekhala. His three daughters, Arati, Tanha, and Raga, are shown standing in the front. A beautifully decorated panel from Nagarjunkonda combines these two scenes - attack and defeat of the Mara's army. Here anthropomorphic image of the Buddha is shown meditating under the Bodhi tree. His left hand is on the lap and right hand is in abhayamudra. The leaves of the Bodhivriksa are partially visible at the back of the halo. 


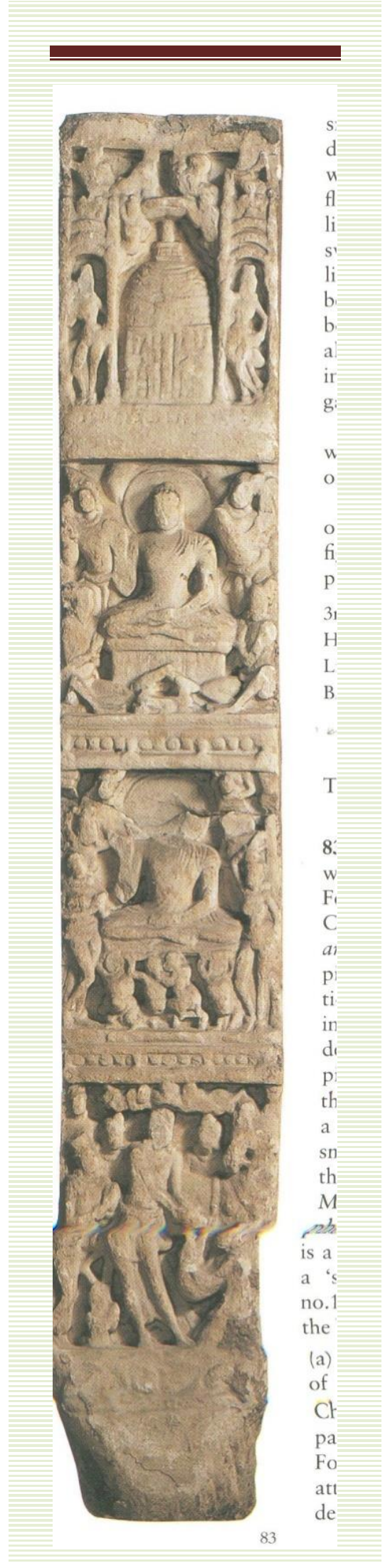

Major Events of the Buddha's Life, Amaravati, British Museum, Courtesy: Knox, Amaravati Buddhist Sculpture, Pl. 83

Unlike the aniconic depiction of Ghantasala, Goli and Nandalapalem we see the anthropomorphic depictions from Nagarjunkonda and Amaravati. In Amaravati, the drum pilasters, which generally depict the four great events of the Buddha's life in a sequence - renunciation, enlightenment, first sermon, and mahaparinirvana. In the enlightenment episode, the Buddha is shown with the dwarf army of Mara and his daughters. Mara's daughters are in either giving a provocative look to the Buddha or they are tired and shown in anjalimudra. Here, the focus is on the image of the Buddha. In such scenes, Mara and his elephant Girimekhala are not shown.

\section{Conclusion:}

Mara's attack on the Buddha and the temptation of the Buddha by his daughters are of great importance in the art of Amaravati school as in most of the depiction it has been associated with the second major events of the Buddha's life, i.e. the enlightenment. In all the depictions, we see the Buddha sitting in abhayamudra and not in the bhumispashamudra. However, bhumisparshmudra 
is related to the defeat of Mara, as he calls the mother earth to bear witness to his victory. Though in the texts, Mara's attack is a persuasion of the Buddha's mind that was in search of enlightenment. As Mara's ten-fold army includes, Lust, Aversion, Hunger, Thirst, Craving, Sloth, Cowardice, Doubt, Hypocrisy, and, Conceit (Mahavastu II, 1952:224-227), the depiction of such emotions cannot be carried through art. Thus, the sculptors of the early phase depicted it in physical form. After the defeat of Mara, his three daughters named, Arati (craving), Tanha (Discontent), and Raga (Lust) came to avenge their father's humiliation by the Buddha. Therefore, they came to seduce the Buddha in the fifth week after his enlightenment. In these depictions, the focus is the Buddha's victory over evil. To notify that, two separate episodes of the story such as Mara's attack and his daughter's provocative behaviour are depicted together. Here, on the one side, aggression of Mara and his daughters is shown and on the other, acceptance of the spiritual superiority of the Buddha with his centralized image, both in aniconic and anthropomorphic form, is depicted. Thus, the sculptors of this region have skilfully illustrated the episode of enlightenment as the victory over all kinds of evils.

\section{References:}

- Asvaghosa, The Buddha-Carita or the life of Buddha. ed. and trans. by Edward B. Cowell New Delhi: [n.pub.], 1894-1895, repr. 1977, Print.

- Beal, Samuel. The Romantic Legend of Sakya Buddha: from the Chinese-Sanscrit. London: Trubner, 1875, Print.

- Cowell, E. B. ed., The Jataka or Stories of Buddha's Former Births. 6 vols Cambridge: University Press, 1895-1907, Print.

- Dehejia, Vidya. Discourse in Early Buddhist Visual Narratives of India, New Delhi: Munshiram Manoharlal, 1997, Print.

- Fausboll, V. Buddhist Birth Stories; or Jataka Tales. trans. by T. W. Rhys Davids London: Trubner, 1880, Print. 
- Jones, J. J. trans., The Mahavastu. 3 vols, London: Luzac, 1952, Print.

- Knox, Robert. Amaravati Buddhist Sculpture from the Great Stupa. London: British Museum Press, 1992, Print

- Mitter, Partha. Much Maligned Monsters: History of European Reactions to Indian Art. Oxford: Clarendon Press, 1977, Print.

- Rea, Alexander. South Indian Buddhist Antiquities. Madras: Superintendent Government Press, 1894, repr. 1897, Print.

- Rinpoche, Chokyi Nyima. and others eds. and trans, The Play in Full: Lalitavistara. [n.p]: Dharmachakra Translation Committee, 84000 Translating the words of the Buddha, 2013, Print.

\section{Dr. Sabita Kumari}

Gujarat Arts and Commerce College

Email ID: sabita.me@gmail.com 